\title{
A REVISTA LABOR ENTREVISTA ROCCO LACORTE
}

O professor Rocco Lacorte é Doutor em Antropologia Sócio pela Universidade de Chicago e pós doutor em Educação pela Universidade Federal Fluminense do Rio de Janeiro. É Professor da Universidade de Brasília e Membro do Núcleo de Estudos e Pesquisas em Filosofia, Política e Educação da Universidade Federal Fluminense do Rio de Janeiro. Tem desenvolvidos pesquisa com base no pensamento de Antonio Gramsci, dedicando-se nestes últimos anos e estudar a educação brasileira e a repercussão do pensamento de Gramsci no Brasil. Essa entrevista ocorreu durante o IV Encontro Internacional Trabalho e Perspectiva de Formação dos Trabalhadores, quando o professor Lacorte proferiu a conferência: Para uma nova abordagem ao conceito de pedagogia em Antonio Gramsci. A leitura da mesma é esclarecedora para entender o pensamento gramsciano.

\section{Revista Labor: Professor Rocco Lacorte, a que se deve, em sua história de vida, o direcionamento para a área de Filosofia e Educação?}

Rocco Lacorte - Bom, a relação com a Filosofia começa muito cedo, porque meu pai, Carmelo Lacorte, era filósofo, mas morreu quando eu estava com doze anos. Por isso, como eu queria continuar conhecer meu pai, ainda mais por causa da perda precoz, umas das maneiras para ficar em contato come ele e tentar conhecer e reconstruir alguns lados dele, foi ler os livros que ele deixou no seu estante em casa.

Contudo, meu pai não foi um filósofo, no sentido tradicional. Ele nasceu em 1929, durante a época do fascismo, na Itália, e, ao crescer, ele desenvolveu uma atitude, digamos assim, de contraste ao fascismo e à retórica; e aos poucos se tornou um intelectual comunista, consciente de que os intelectuais, ao mesmo tempo, podem e devem desenvolver um papel político. Ele estudou em uma das melhores universidades italianas (Normal Superior de Pisa, que foi fundada por Napoleão - ganhou uma bolsa e estudo lá). Ele morreu jovem, com 53 anos, mas, na época, era um intelectual que atuava não só teorica mas também politicamente, um intelectual marxista reconhecido dentro e fora da Itália e, portanto de uma certa influência e importância - o que não deixou de me afetar. Aí, além da relação pessoal e particular entre pai e filho, eu vivia, por um lado, numa atmosfera, num ambiente de filósofos e políticos da área da esquerda radical italiana e europeia. Mas como meu pai era, ao mesmo tempo, muito curioso de conhecer a fundo a realidade, ele tinha também relações com pessoas da parte adversa. 
Em suma, eu vivi num ambiente - o dos anos setenta e primeiros anos oitenta na Itália - do qual absorvi muitas das ideias e experiências. Era um ambiente muito rico de sugestões e contradições, do ponto de vista cultural e político, no qual se passou de uma fase de lutas, até com éxitos trágicos, a uma fase de progressiva desativação do próprio conflito social, cultural e político - com as palavras de Gramsci poderiamos dizer que houve uma progressiva passagem de uma fase onde houve uma tentativa de revoluçaõ ativa (desde o final dos anos sessenta até aproximadamente a metade dos anos settenta) a uma de "revolução passiva" ou "revolução restauração" - uma nova fase de revolução passiva, num país cuja unificação, no século XIX, já foi realizada "pelo alto" através desse tipo de estratégia politica. De fato, a partir da segunda metade dos anos setenta, se desencadeia progressivamente o processo da derrota e fragmentação das forças de esquerda. Me lembro muito bem, embora menino, como o meu pai denunciasse e criticasse, e com muita energia, já então, a maciça "migração", ideal e material, de um grande número de intelectuais do Partido Comunista Italiano (PCI), ou mais em geral, da área de esquerda para o campo dos adversários, da direita política e cultural. Isso explica também por que ele foi entre os que contribuiram, a um certo ponto, a fundar um novo partido de esquerda, Democracia Proletária, a esquerda do PCI.

E, por isso, quando ele faleceu, na primavera de 1982, para mim, não se tratou somente de um evento natural. Inserí desde o início a morte dele no quadro daquela histórica derrota do pensamento e da ação revolucionários na Itália e na Europa de então. Contudo, esses eventos dramáticos, nos quais se combinava o "trágico destino" de um indivíduo e a crise de inteiros povos, na Itália, assim como na Europa - são os anos nos quais se intensifica a ofensiva cada vez mais intensa, brutal, capillar, do neoliberalismo - representaram ao mesmo tempo um fortissimo impulso a me autoeducar, seguindo o modelo exemplar que meu pai representou (e não apenas para mim), no qual se uniam a vontade e prática de luta para emancipar os oprimidos e o desdobramento das capacidades teóricas e de análise das situações históricas.

Um outro lado da minha formação tem muito a ver ainda com o fato que meu pai não separava trabalho teórico de trabalho prático. A família do meu pai é de origem camponesa, aí nós sempre voltamos ao campo para trabalhar um pouco. E, em breve, uns dos lados mais importantes e costante da minha vida familiar e diária foi sempre também o de manter e construir relações com os pescadores, os camponeses, em uma palavra, com os trabalhadores e subalternos - que na Itália significava também relações entre língua nacional e dialetos, e entre culturas e aspectos culturais diferentes. 
A primeira aproximação com o marxismo foi involuntária, num certo sentido. Porque eu cresci nesse ambiente vário e complexo, e absorvi muito, mas a perda do meu pai constituiu, como disse, um desafio para continuar aquelas ideias de mudança, de luta na Itália dos anos oitenta, noventa. E nas zonas entre a Escola Superior e a universidade, um amigo de meu pai foi o que me ajudou com as leituras no marxismo. Se chamava Giorgio Baratta, um autor conhecido na área dos estudiosos de Gramsci. Foi ele quem, a partir da segunda metade dos anos oitenta, impulsionou passo a passo, com grande energia e paciência, um trabalho coletivo para interpretar Gramsci a partir da edição crítica de Valentino Gerratana (1975), na qual os textos foram publicados, quanto mais conforme critérios filológicos e a ordem cronológica na qual o próprio Gramsci os escreveu e ordenou: daqui originou-se, ao nível nacional e até internacional, um novo movimento de estudos e discussões que levaram a novas interpretações de Gramsci, e ao qual é ligada a fundação da IGS-Itália em 1987.

Aí eu comecei a ler Marx e Gramsci com mais sistematicidade, porque o Baratta me fornecia muito material. Eu estava muito interessado. Mais tarde, como estudante na universidade, eu aproveitei para aprofundar os meus fundamentos filosóficos e culturais e o estudo dos autores nos quais eu sempre estava interessado: Marx, Gramsci, Lênin, além de pensadores clássicos, entre os quais se coloca aquele intelectual que expressa o pino da filosofia clássica: Hegel.

A respeito da Educação, o direcionamento vem da minha experiência de vida, porque depois de ter estudado filosofia e história na Universidade La Sapienza, de Roma, eu fui fazer Mestrado e Doutorado nos Estados Unidos. Contudo, a um certo ponto, eu encontrei um professor de pedagogia, Giovanni Semeraro, da Universidade Federal Fluminense, em uma conferência no Canadá. Ele me falou que na UFF havia um grupo de pesquisa sobre Gramsci. E como nos EUA eu pesquisava sozinho, achei muito melhor alcançar esse grupo no o Brasil, para pesquisar sobre Gramsci também no campo da Pedagogia. Esta experiência foi muito importante porque me ajudou a entender de uma forma ainda mais aprofundada que o princípio norteador do pensamento de Gramsci é, com efeito, um princípio “pedagógico”, um aspecto na qual eu não tinha focado bastante antes. Aí eu comecei a aprender melhor sobre o papel fundamental da própria "pedagogia" na formação dos seres humanos. E comecei a refletir sistematicamente sobre esse assunto.

Por isso que hoje venho aqui para tentar uma nova abordagem ao princípio pedagógico gramsciano, que é, ao mesmo tempo, uma abordagem que Gramsci faz repensando os clássicos do marxismo e a sua própria experiência de vida. Estudar este princípio é muito 
importante para desenvolver e fortalecer o marxismo, para atualizá-lo em relação ao nosso presente. Isso creio que seria uma pequena resposta à primeira questão.

\section{Revista Labor: Já respondeu também a segunda, eventualmente a terceira. Se considerar que esse professor italiano foi seu mentor, foi seu guia nesse processo com relação a Marx e Gramsci, que elementos do pensamento gramsciano lhes são mais caros?}

Rocco Lacorte - Vou responder às duas perguntas, 3 e 4, ainda, porque esqueci de falar que a grande questão que Giorgio Baratta me colocou quando eu estava com 15 anos era: "mas o que é o materialismo histórico?”. Eu, na minha ignorância da época, respondi (mais ou menos): "É a dialética aplicada à história". E ele, porém, me falou que não era exatamente assim. Mas nem Baratta teve a resposta definitiva. Aí foi em 1985. Começamos a trabalhar para chegar a uma resposta a esse problema que Baratta colocou - e que, obviamente, colocou porque é central no marxismo, antes, e sobretudo depois, da Carta que Engels enviou a Joseph Bloch em 21 de setembro de 1890, na qual enfrenta o problema do papel das "superestruturas" a respeito da "estrutura", mas não deixando claro como contretamente se daria a relação dialética entre elas. Daqui se originou um intenso debate no marxismo russo, cujos assuntos foram depois retomados criticamente nos Cadernos do Cárcere de Gramsci, que os sintetizou na que se tornou a sua questão teórica central, a do problema da "unidade de teoria e de prática”.

Então, ligando-me à questão número quatro ("que elementos do pensamento gramsciano me são mais caros?"), este é um dos elementos mais caros: precisamente o problema da relação entre teoria e prática. È por meio da leitura de Gramsci que eu encontrei a minha resposta a essa pergunta, ou seja, como podemos explicar o conceito de materialismo histórico. Esta era a questão da qual eu parti.

No enquanto, nos anos da universidade, eu estudei também filosofia da linguagem e teórias linguísticas - na verdade, algo ainda pouco trabalhado, em geral, nas universidades italiánas, na época dos anos 1980 e 1990 (especialmente no Centro e no Sul da Itália). A minha sorte foi que no Departamento da universidade de Roma havia um grupo de linguistas e filósofos da linguagem muito ativos, entre os quais cabe lembrar Tullio De Mauro e Lia Formigari, cuja abordagem histórica e social aos problemas da língua e da línguagem me influenciou muito. 
Desta forma, lendo e relendo os Cadernos sobre essas premissas, eu vi que essa questão da relação entre teoria e prática (ou entre "linguagem teórica" e "linguagem prática") é, para Gramsci, o princípio fundamental e norteador da "filosofia da práxis" - expressão que ele retomou da tradição marxista anterior, em particular de Antônio Labriola, e por meio da qual ele "traduziu" a velha expressão de "materialismo histórico", não tanto por causa da censura carcerária, mas, mais do que tudo, para expressar de forma melhor o caráter original, inovador e autônomo do próprio marxismo, entendido como filosofia que rompe absolutamente com as concepções tradicionais, ao se conceber contemporaneamente como história e hegemonia, e vice-versa que encontra na história e na política - em uma palavra: no movimento da vida real - uma "linguagem filosófica" implícita a ser elaborada e explicitada teoricamente.

A teoria da unificação entre teoria e prática é a base sobre a qual Gramsci constrói todos os seus "conceitos científicos" - os que, tradicionalmente, se chamam de "categorias". De fato, ao repensar como se dá a relação entre teoria e prática, ele chega a mudar o próprio significado do termo categoria. A partir dessa nova teoria, ele seja cria novos conceitos, e um novo modo de interpretar o que é "conceito" (isto é, o que é "pensamento-linguagem”), seja amplia criticamente todos os velhos e tradicionais.

Posso fazer algum exemplo? Em primeiro lugar, no conceito de política, para Gramsci, se expressa sim a política do político de profissão, mas este conceito não se limita apenas a isso. Para Gramsci, a política se dá também em todas as atividades humanas que sejam "racionais", isto é, aceitas e atuadas com uma certa "regularidade" por uma determinada comunidade de seres humanos, em um certo espaço e tempo: neste sentido, toda atividade humana "racional" é "política". Desta forma, também as atividades teóricas (as expressas pelas assim chamadas “superestruturas") são um modo de fazer política, mas num sentido mais amplo (pois não atuam diretamente e imediatamente nos lugares da política entendida no sentido estrito). È assim que Gramsci amplia o sentido de política: a política como trabalho especializado de pessoas treinadas para fazer o trabalho específico de político, mas também todas as atividades humanas que têm efeitos de transformação e de organização da vida humana. No caso da filosofia da práxis, a política, tomada tanto de acordo com o sentido estrito quanto com o mais amplo, é conscientemente assumida como atividade (vontade coletiva) que organiza e transforma o mundo (as vontades coletivas existentes, realizadas e a natureza) de maneira revolucionária, isto é, como práxis.

Em segundo lugar, para fazer outro exemplo, podemos tocar no conceito de linguagem, pensado por Gramsci de maneira absolutamente inovadora, especialmente a respeito da época 
na qual ele o elabora - embora permaneça atual e estumulante ainda hoje. A linguagem, para ele, não é mais só a linguagem verbal, mas é concepção de mundo e práxis. Com efeito, para ele, a linguagem (quer comum quer teórica e científica) deve ser incluida entre as atividades históricas humanas: isto é possível, pois se pode demonstrar que ela é tal quando e enquanto consegue se tornar "história", ou seja, elemento "racional".

Devemos rapidamente retomar este conceito de racional, ao qual temos acenado acima, porque ajuda a entender como Gramsci intepreta o fenômeno da linguagem. "Atividade racional" significa, para ele, expressão humana histórica e cultural que remete a algo não "arbitrário", enquanto aceito (criticamente ou menos) e atuado com regularidade pelas massas. E, com base nessas premissas, a própria palavra "atividade" significa atividade humana histórica, organizadora-transformadora, em uma palavra, práxis, a qual coincide com todo o que tem efeitos políticos-históricos concretos, à medida que consegue (e deve) tornarse historicamente permanente. Mas, na verdade, o conceito gramsciano de racional é ainda mais abrangente, muito mais do que podemos pensar. Pois, posta politicamente $e$ historicamente a sua "racionalidade", qualquer atividade humana histórica (práxis) expressa e simboliza algo determinado, e portanto é "linguagem" ou "atividade linguística" - também no sentido que pode ser interpretada, compreendida e, por isso, traduzida e conhecida; mas, ao mesmo tempo, qualquer linguagem-expressão-símbolo ("racional") é atividade transformadora do mundo, ou seja práxis. Este conceito de "racional" é fundamental, em Gramsci. Podemos dizer que é outro elemento caro dele, que, dialeticamente, implica o de "irracional" ou "arbitrário". A partir dele, e do conceito de tradução, aliás implícito nele, Gramsci amplia todos os conceitos tradicionais e os resignifica.

Dito isso, como Gramsci amplia a noção de linguagem? Uma determinada linguagem, na medida em que é aceita por uma comunidade de seres humanos e se torna a norma de ação (ideologia) deles, se torna história; de fato, na medida em que uma comunidade de seres humanos acredita numa certa linguagem-concepção de mundo, ela atua conforme essa concepção, produzindo diariamente efeitos organizadores e transformadores da realidade na qual eles vivem (cabe considerar que também para conservar um dado mundo é preciso atuar mudanças). Ora, na medida em que a linguagem tem efeitos de organização e transformação "política" na sociedade, se amplia seja conceitualmente seja realmente, pois é a própria linguagem que se torna sociedade (transformada), "história". E é nesse "se tornar" ou "ser traduzida" (para a realidade histórica) que ela demonstra a sua verdade, realidade, poder e imanência (ou seja, seu caráter terreno, enquanto atividade humana, a qual não pode ir além 
deste mundo, da política, ou, para falar difícil, não os pode transcender). Portanto, pelo que se pode ler nos Cadernos, a linguagem verbal, na realidade, constitui apenas uma parte do processo linguístico. Para exemplificar muito sinteticamente, o "momento" no qual a linguagem teórica (ou filosofia) de Marx é traduzida por Lênin num novo Estado, no qual a teoria se torna ação, não representa algo que não seja também linguagem, embora assuma formas diferentes da verbal (as da realização política e social); mas é, muito pelo contrário, um momento que pode ser interpretado como o da realização crítica daquela linguagem, e portanto como o momento no qual a linguagem teórica se torna linguagem real e concreta, isto é, linguagem "racional", pelos seus efeitos "políticos" ou "ideológicos" e, por isso, "históricos". Desta forma, se compreende que também o conceito de expressão, ao qual acenei acima, se amplia, nos Cadernos. Para Gramsci, afirmar que uma atividade humana teórica ou prática (e a atividade linguística, para ele, é uma das atividades humanas) - é expressão de uma sociedade significa não só que ela depende de uma determinada realidade (como o efeito da causa, mecanicamente) e a reflete estáticamente como uma imagem reflexa num espelho, mas também que ela possui ao mesmo tempo um caráter prático, político ou transformador e que é um "processo".

Aí, para Gramsci, a linguagem verbal é uma das possibilidades que nós temos para nos expressarmos, mas não a única ou necessariamente a que mais possa influenciar um determinado público conforme as diferentes circunstâncias históricas, culturais e sociais embora a linguagem teórica seja a que mais do que outras é capaz de organizar a realidade de forma homogênea e coerente. Contudo, o que, por exemplo, se expressa por meio da elaboração numa linguagem filosófica ou teórica, pode ser expresso também através de "soluções linguísticas" diferentes: por exemplo, dançando ou pintando ou tocando ou realizando uma dada obra de arquitetura. Naturalmente, se trata de níveis e tipologias de elaboração linguístico-expressiva diferentes e que podem ter diferentes intensidades e modos de afetar uma determinada comunidade. E disso, para Gramsci, se deve ocupar uma dada política da cultura.

Um exemplo sobre como ele amplia a noção de linguagem, é o do conceito e termo de "Estado". O conceito de Estado se encontra formulado, no século XVII, de uma certa forma e para expressar um certo significado e realidade. O Estado Absoluto remete a um rei e a uma monarquia de um certo tipo. Depois, com a Revolução Francesa e a Revolução Russa, o conceito de Estado muda e, de consequência, mudam também as formulações linguísticas dele. Mas por que muda o conceito? Porque a palavra "Estado" leva, dentro de si, a história. 
Essa palavra expressa as mudanças históricas. Então, no dicionário que é escrito depois da Revolução Russa, nós temos que acrescentar novos significados e formulações a essa palavra. A palavra "Estado", que se refere ao Estado russo, pelo seu aspecto exterior, embora seja veiculada por meio do mesmo significante utilizado no passado, não expressa mais o Estado da monarquia absoluta, nem o da República francesa revolucionária de 1789, mas o Estado dos Conselhos de fábrica (dos Sovietes). Então, além (ou melhor, dentro) da aparente identidade do próprio termo-significante-Estado há uma história, a qual não é puramente linguístico-conceitual, ou seja, de puros conceitos e palavras. Na verdade a história desses conceitos-significados de Estado, que é uma história de inovações semánticas, remete e expressa inovações históricas reais. Mas o que significa isso? Tal vez que existam duas histórias parallelas ou separadas, uma semántico-linguística ("superestrutural”) e uma outra real ("estrutural”)? E qual seria a verdadeiramente a real das duas? O seriam duas realidades absolutamente diferentes? Na verdade, segundo Gramsci, a criação do novo Estado russo não foi o resultado de uma ação puramente política: à medida que o novo significado do termo Estado remete a um elemento lógico-linguístico que se insere numa mais ampla e inovadora concepção de mundo (o marxismo-leninismo), pela qual se concebe ao mesmo tempo um novo Estado expressão de novas necessidades e exigências dos subalternos, para revolucionarem todas as formas tradicionais de estado; e na medida em que essa nova concepção se tornou a linguagem ideológica (terreno real de conscientização e norma de ação) de inteiras massas humanas - as quais atuaram conforme ela e a nova ideia de Estado não apenas toda a concepção, mas também, mais em particular, a nova ideia-significado de Estado contribuiu para mudar o velho mundo e Estado, assim demonstrando de ser não só atividade linguística (entendida no sentido estrito), mas, ao mesmo tempo, atividade "política", ou seja, organizadora e transformadora do mundo (embora não diretamente e no sentido estrito do político de profissão). Em outras palavras, na medida em que a nova linguagem-concepção de mundo e, mais em particular, o novo termo-conceito (ou significante-significado) de Estado (que superficialmente não se percebe como novo, pois o significante é o mesmo do que se usava no passado) se realizou e se tornou uma nova realidade histórica - isto é, "racional" - ele demostra de não ser apenas um "reflexo" lógicolinguístico (mecânico ou estático) da realidade, e sequer algo puramente convencional, mas linguagem-pensamento que é contemporaneamente atividade transformadora, dinâmica, a qual contribui, e contribuiu no caso russo, enquanto tal, ou seja enquanto atividade linguística que se distingue de outras atividades humanas, a revolucionar o velho mundo. Neste sentido, 
ela mostra de ser mais do que modo de sentir e de pensar, e cultura (nos seus vários níveis), isto é, puro conhecimento e linguagem, pois é "história". E é história porque é "politica", porque se torna história através do seu ser política, e por ser traduzida na linguagem da política (no sentido mais estrito) e em ação prática. Desta forma, se demonstra que também a línguística é uma atividade humana histórica (isto é, história real ou práxis), e que não há duas ou mais histórias separadas. Portanto, a história real é "uma", na medida em que é sempre o resultado e a síntese, mais ou menos "homogênea", de todas as atividades históricas ("práticas" e "teóricas") que contribuem - politicamente, ideologicamente - a produzir, pelos seus efeitos concretos, um determinado evento, situação e/ou mundo histórico. E o conjunto das atividades humanas - a vida - de uma certa época histórica é contemporaneamente a "linguagem real" daquela época. Então, compreendemos como, dialeticamente, por um lado a linguagem verbal se prolongue na realidade (mudando a sua tipologia) e seja realidade histórica (quando e enquanto se torne tal, isto é, se traduza em algo "racional"), e como, por outro lado, a própria realidade histórica seja sempre imbuida de linguagem-pensamento, enquanto é, ao mesmo tempo, a realização de uma determinada linguagem-concepção de mundo. È assim que Gramsci amplia a noção de linguagem. A linguagem não é apenas algo que se limite à morfologia e sintaxe ou ao momento da interpretação, mas abrange também o momento da transformação e realização histórico-política; a qual, por sua vez, pode ser transformação por fins reacionários e conservadores (luta para conservar um dado mundo) ou revolucionários. Com efeito, para Gramsci, a lingagem sempre expressa uma determinada "vontade", isto é, uma determinada "política" ou "prática" e, neste sentido, por si mesma não é nem reacionária nem revolucionária, mas é uma expressão social-cultural-política dos interesses e necessidades (individuais e coletivas) que elabora e elaborando-as elabora ao mesmo tempo a vontade como vontade coletiva. Desta forma, se entende que a linguagem tem uma história própria, enquanto linguagem, que é história das suas inovações, só que estas últimas expressam mais em geral as inovações culturais coletivas, as quais por sua vez expressam as históricas, as quais são realizadas por meio da politica - mas entre as atividades políticas no sentido amplo há também a própria linguagem.

São só uns aspectos e conceitos um pouco complexos, que estou tentando resumir de forma brutalmente rápida, mas a ideia fundamental é que refletindo sobre a relação entre teoria e prática de forma inovadora, por meio da elaboração da tradutibilidade, Gramsci transforma todas as categorias do pensamento tradicional e elabora novas categorias. 
Nós podemos entender melhor a categoria de hegemonia melhor só se entendermos que a hegemonia é um fato, ao mesmo tempo, político e cultural, onde, por um lado, a cultura é, ao mesmo tempo, política, porque a concepção de mundo (o elemento cultural, mais em geral) tem uma certa força hegemônica de fundo, tem efeitos reais; obviamente, quando e enquanto os tem. Então, cultura é política, no sentido amplo. E, por outro lado, para Gramsci, a política é seja política no sentido estrito, seja num mais amplo, como acontece com o conceito de hegemonia, isto é, política que implica ao mesmo tempo aquela dimensão da política que é a atividade cultural (a filosofia, por exemplo: é bastante pensar em como todas as leis aprovadas pelos parlamentos traduzam na linguagem juridico-política concepções de mundo, linguagem filosóficas diferentes ou até em contradição...). Tudo isso implica, por sua vez, todo o discurso de Lênin, que, a partir dos anos 1921, mais ou menos, começa a refletir sobre o fato de que não é o bastante mudar uma sociedade através da ação meramente política. Depois da fase da luta política (até armada, que, de qualquer forma, nunca é puramente política ou puramente armada), é necessário mudar o modo de pensar e atuar, a cultura, de toda uma população. Você tem que levar a (nova) cultura à população para que essa população seja capaz de trabalhar nas indústrias que vão inovar a produção, o trabalho - e deste jeito o trabalho "intelectual" (a elaboração das "superestruturas") pode ser visto contemporaneamente como necessário para inovar o trabalho "manual" e a "estrutura" (e vice-versa). O "trabalho" não é um conceito estático, em Gramsci, mas implica sempre uma dialetica entre o manual e o intelectual, na qual nenhum dos dois deixa de ser (e de "educar"), ao mesmo tempo, o outro: o primeiro como realização do segundo e o segundo como elaboração do primeiro. Para satisfazer as novas necessidades, precisamos interpretá-las, formulá-las, comunicá-las, etc.; mas, para que seja assim, precisamos nos tornarmos capazes de fazer isso, de produzir meios e capacidades culturais ("linguísticas”) e de um enorme trabalho pedagógico-cultural, visando formar intelectuais orgânicos, desenvolver atividades e meios culturais sempre novos e adequados à realidade presente, para traduzir as novas exigências em novas concepções de mundo ou para inseri-las em concepções já inovadoras. Mas essas linguagens-concepções devem ser novamente traduzidas, divulgadas, chegar ao trabalho "manual", o qual se inova no momento em que o ser humano que trabalha as compreende e aceita. Por sua vez, porém, esta aceitação quase nunca é acrítica, pois na prática as próprias concepções são averiguadas e verificadas e, se necessário, criticamente amelhoradas ou até demitidas. Quando acontece essa dialética entre atividades teóricas e práticas se cria uma unidade entre "ciência e vida", para 
utilizar uma das metáforas de Gramsci, a qual constitui o princípio pedagógico que é o cerne da filosofia da práxis.

Então, eu diria que, para mim, o conceito central em Gramsci é o conceito de unidade, ou ainda melhor, de unificação (pois esta palavra expressa melhor o sentido de um trabalho e movimento) que se dá como uma tradução, entre teoria e prática, filosofia e política. A tradução é recíproca, ainda que nunca seja perfeita num sentido absoluto (mas o próprio conceito de perfeição muda em Gramsci e se encontra adequado a uma concepção histórica da atividade humana e dos produtos desta atividade que sempre precisam ser atualizados, criticados e perfecionados). Então, esta nova "categoria" gramsciana da tradutibilidade representa a justificação (e explicação) teórica — que a relação entre teoria e prática é uma relação dialética. Gramsci é o único marxista na sua época que faz isso (na verdade, Lênin também tentou e Gramsci explicitamente admite ter partido dele). Ele nós fornece finalmente uma justificação: não se limita meramente a afirmar que entre teoria e prática tem uma relação dialética (pois essa afirmação encontramos em inúmeros marxistas); mas explica por quê e como se dá, como acontece essa dialética - que é o que Engels, na sua carta de 1890, e depois os grandes teóricos russos (Plechanov, Buharin etc.) não chegaram a fazer, apesar da importância dos resultados teóricos que conseguiram, os quais não serão desconsiderados, e sim criticados, por Gramsci, nos Cadernos, a partir das "dicas" de Lênin, Marx e do próprio Engels, precisamente no espírito de um aprofundamento e fortalecimento do marxismo, para destacar o seu estatuto de filosofia original e autônoma, e não para se afastar dele, como alguém ainda hoje tenta afirmar.

Apesar da sua urgência e importância, o tema da tradutibilidade, da tradução entre prática e teoria, entre filosofia e política é ainda muito pouco estudado - mas é a metodologia da qual nós necessitamos para interpretar e analisar os fenômenos históricos e da nossa época. Aliás, Gramsci sempre traduz os conceitos da tradição para atualizá-los e criticá-los, adaptando-os à realidade do presente. Então, explicado isso, podemos entender porque, para mim, a "categoria" (entre aspas, pois se trata gramscianamente de algo lógico e ao mesmo tempo histórico) fundamental de Gramsci é a categoria de tradução e tradutibilidade. Ainda aqui, a própria tradução não é mais o conceito restrito da tradição, porque não é mais a tradução de um livro em inglês para um livro em outra língua: não é algo estritamente linguístico nem livresco. É, primeiro de tudo, a tradução entre filosofia e política, dois elementos que a tradição de pensamento ocidental predominante separa totalmente. Na medida em que esses dois elementos, ou atividades, são traduzíveis, se demonstra que, embora diferentes, são a 
expressão da mesma atividade, da mesma práxis (para evitar que esta última frase seja interpretada como contraditória, cabe destacar que o termo "expressão" dever-se-ia aqui entender gramscianamente, ou seja à luz da própria tradutibilidade: isto é, como já dissemos, como algo que se refere a um elemento ou atividade que não apenas reflete mas produz mudanças, (nova) realidade. Desta forma as "duas", teoria e prática, não só derivam de, mas, ao mesmo tempo, produzem uma determinada realidade histórica). Portanto, quando, embora sejam atividades diferentes, uma determinada teoria e uma dada prática produzem efeitos reais, dos quais nasce e se (re)produz a mesma realidade ou práxis, se pode dizer, pelos seus efeitos, isto é a posteriori, que são reciprocamente traduzíveis e, então, que não remetem a opostos contraditórios e sim que são a "mesma" realidade. Desta maneira, se entende como Gramsci derrube a tradição predominante de pensamento ocidental, pela qual teoria e prática remetem a duas realidades absolutamente e metafisicamente diferentes, e que "mesma", acima riferido a realidade, remete a uma "identidade" a qual se produz e reproduz por meio de atividades ou elementos diferentes, e que, portanto, não é mais a identidade estática da tradição, mas um equilibro - dialético e dinâmico - entre opostos não contraditórios).

Ora, esse novo conceito de tradução e tradutibilidade nos ajuda a entender melhor também o conceito de práxis. E práxis é, se quisermos, o modo no qual Gramsci fala - duma forma inovadora que implica o conceito de tradutibilidade - do conceito de trabalho. Trabalho como unificação de trabalho intelectual e trabalho manual.

A partir desse conceito de tradução, nós alcançamos um nível mais profundo por meio do qual (re)ler o pensamento de Gramsci, mas de Gramsci como leitor, acima de tudo, entre outras fontes, dos clássicos do marxismo. E, através dele, nós podemos reler Marx, Engels, Labriola e Lênin. É muito importante fazer este estudo, que produz como um efeito "domino": uma vez que você tenha entendido isso, começa a ter um novo entendimento de toda a tradição marxista, que Gramsci sintetiza na sua concepção.

Aliás, para mim, todas as categorias que ele elabora - hegemonia, linguagem, Reforma e Renascimento, Revolução passiva (que são só umas das suas categorias muito importantes) , implicam sempre a teoria da unificação entre teoria e prática, intelectuais e povo. Porque, por exemplo, o Renascimento, na Itália, é uma época na qual os intelectuais se afastam do povo. Aí é o emblema do intelectual tradicional, que expressa também a concepção da teoria como algo de isolado, de separado da prática. A Reforma é um momento no qual Lutero, o que faz? Traduz a Bíblia do latim para o alemão, para que todo mundo na Alemanha se possa tornar intérprete da Palavra de Deus, a qual, desta maneira, cessa de ser monopólio de uma 
casta e da Igreja Romana. Aí a Reforma é um momento revolucionário, para Gramsci, pois se entende bem que essa tradução não é apenas algo livresco ou puramente linguístico, mas contemporaneamente um ato político. É um momento no qual a "teoria" — o que está escrito nos livros e que no mundo renascentista ficava separado do povo - se encarna no povo, embora até certos limites. Agora o povo tem acesso à cultura e, nos Cadernos, o termo Reforma se torna uma metáfora desse acesso à cultura - mas esse processo histórico mostra um lado novo da cultura: que a cultura é ao mesmo tempo "política", meio de transformação, não algo puramente livresco ou um conjunto de noções abstratas. Mais tarde, ao longo da elaboração dos conceitos nos Cadernos, em concomitância com uma ulterior elaboração da tradutibilidade, por meio da qual Gramsci entende plenamente que teoria e prática são equivalentes, ele resgatará a categoria de Renascimento. Mas aqui não tem espaço para continuar a falar desta temática. Era apenas para mostrar as implicações, importância e papel da tradutibilidade em relação à elaboração das novas categorias nos Cadernos.

Considerado quanto falava acima, quero dizer algo sobre o que se encontra no ponto 10 da sua lista de perguntas para mim. À pergunta sobre quais são os meus interesses culturais não posso responder por razões de espaço, mas quero falar brevemente que eu entendo "cultura" com Gramsci. Quer dizer, cultura é todo tipo de atividade humana na qual o ser humano se "expressa", mas essa expressão é tomada no sentido de "expressão racional", ou seja, aceita por uma comunidade mais ou menos grande de seres humanos. Cultura não é só livros ou as atividades mais refinadas, mas também qualquer atividade (coletiva), até prática, humana, que é necessária para que uma certa comunidade possa sobreviver, viver e se reproduzir - por meio da produção e reprodução das relações entre os seres humanos e com a natureza; quer dizer, a cultura tem sempre a ver, diretamente ou indiretamente, com a produção, organização e transformação de todas essas relações no espaço e no tempo. Em suma, posso falar que os meus interesses culturais não consistem apenas em cultivar obras e atividades "refinadas" (das quais Gramsci, com certeza, é uma parte, num certo sentido), mas estão também voltadas a desenvolver relaçãoes humanas e de conhecimento com os trabalhadores dos quais falava no início.

Revista Labor: Rocco, eu vou interromper para acrescentar um ponto, porque você frisou, quando disse irracional, disse "dialeticamente irracional". Como o Gramsci trabalha essa questão do racional e irracional? 
Rocco Lacorte - Seria, em poucas palavras, algo que ele expressa quando fala, mais em geral, em vários apontamentos, dos conceitos de "racional" e "arbitrário" ou "arbítrio". Gramsci afirma, em mais de uma ocasião, que o racional é o elemento aceito por uma comunidade; pode ser, por exemplo, uma visão de mundo, aceita, que se torna norma de ação de uma comunidade - e pode durar por dez anos ou dez milhões de anos, mas chega um dia no qual vai necessariamente acabar. Racional, para ele, é algo que tem um efeito organizador e transformador numa determinada realidade histórica. Irracional é o elemento ou a atividade que está em luta com o que é aceito e que não consegue naquela época ser aceito, mas, lutando contra o racional, contribui a determiná-lo como racional.

Parafraseando o que se encontra em vários apontamentos nos Cadernos, podemos dizer que, para Gramsci, nas várias fases do movimento histórico há luta entre racional e irracional. Por exemplo, se pode pensar no movimento e êxito da luta entre a burguesia e a nobreza durante da época da Revolução francesa: na qual a burguesia da cidade encarna o "racional" ou "geral” (à medida que conseguirá a aliança com os camponeses e a hegemonia) e a nobreza o "particular" ou "irracional". De fato, na medida em que a linguagem-ideologia-concepção de mundo da burguesia - em particular a linguagem dos Jacobinos - consegue ampliar os interesses dessa classe, ao expressar e encontrar as necessidades e interesses comuns entre ela e as outras camadas do "terceiro estado" (ampliando, ao mesmo tempo, a frente de luta contra a nobreza, ao tirar dela as vastas áreas do consenso dos camponeses), essa "linguagem" (que é uma relação ativa entre a realidade e a capacidade dos burgueses jacobinos de elaborá-la criticamente e de fazê-la reagir sobre as camadas sociais e culturais da sociedade, mudando suficientemente a mentalidade, vontade e comportamentos delas) transforma, ao mesmo tempo, a própria burguesia e o próprio terceiro estado, fazendo-o passar de grupo social fragmentado para uma classe social mais homogênea e forte, capaz de atrair a si outras camadas sociais - entre as quais precisamente os camponeses, os quais tradicionalmente gravitavam entorno do discurso e cultura reacionários dos nobres. Desta forma, a burguesia conseguiu sair do seu ser "corporativa" ou "particular", através de um processo de alianças políticas e sociais moleculares e complexas que não dar-se-iam sem a atividade de traduçãoelaboração e expressão-comunicação-difusão-tradução da nova linguagem - expressando esta última as novas necessidades reais da sociedade francesa. Através desse processo, a burguesia consegue convencer outras camadas e grupos sociais que a nova linguagem dela é a de todo o povo francês. È assim que, para Gramsci, a burguesia consegue não apenas universalizar concretamente esta sua linguagem, mas torná-la hegemônica (tornando assim hegemônica 
toda a burguesia). Este exemplo histórico paradigmático serve para mostrar que, nos Cadernos, racional $=$ hegemônico $=$ histórico : esta equivalência coincide com a passagem de um elemento social da fase na qual ele é um elemento social, cultural e político que ainda não sabe se se tornará elemento historicamente permanente, mas que luta para se tornar tal - pois enquanto luta é sempre racional e irracional - à fase na qual se torna elemento "racional", historicamente permanente, isto é, uma nova sociedade, cultura, história, e até uma nova civilização. Portanto, o momento da conquista de uma determinada hegemonia é o no qual um determinado grupo ou conjunto de grupos sociais e a sua "linguagem" se traduzem em história, se tornam "racionais", assim demonstrando contemporaneamente o poder político (e por isso histórico-concreto) das atividades (até as teórico-linguísticas) que elabora e excerce e que o caracterizam. Desta forma a burguesia demonstra que não é um elemento "arbitrário" ou "irracional". Ao contrário, a nobreza sai derrotada, pois não consegue mais tornar universal a sua "linguagem", que então fica "corporativa", e neste sentido se torna uma expressão "particular" e "irracional": a sua linguagem se torna "velha linguagem", e "arbitrária" (relativamente à da burguesia), pois não consegue mais afirmar seu poder hegemônico, o qual desaparece ou se torna extremamente limitado e essencialmente ineficaz do ponto de vista histórico.

Vale a pena destacar, porém, que a nobreza (e a sua linguagem-concepção de mundo), antes de ser derrotada, se caracterizava "essencialmente" (= historicamente) pela sua "racionalidade". Portanto, mais em geral, o que Gramsci pensa a respeito de um elemento social-histórico, e até de uma singular atividade humana, "prática" ou "teórica", é que não se pode saber o que é racional ou irracional antes, a priori, mas sua racionalidade ou irracionalidade se "define" dialeticamente na (e através da) luta (de todas as formas de luta, que historicamente são expressas, tanto do ponto de vista ideológico-político-históricocultural quanto militar). Em outras palavras, todo elemento, enquanto é um elemento em luta, é sempre racional e irracional ao mesmo tempo: a nobreza era racional e se tornou irracional mas o fato da progressiva afirmação da burguesia mostrou que dentro da nobreza haviam, ao mesmo tempo, elementos de irracionalidade, já antes que ela se tornasse um elemento "irracional"; também o socialismo ou comunismo poderia ser considerado "irracional" a respeito do liberalismo, expressão ideológico-cultural da burguesia, considerada como a classe hegemônica e que predomina na sociedade moderna e contemporânea. Mas seja na medida em que a nova ideologia e concepção visa expressar e expressa as necessidades e exigências dos subalternos que a burguesia ignora ou negligencia, seja na medida em que 
historicamente se realizou, ainda que parcialmente, no tempo e no espaço, isto é, conquistou uma parte de hegemonia em determinadas sociedades e culturas (ou partes delas), o próprio socialismo ou comunismo mostra também de ser "racional" e, sobre tudo, que vale a pena e se deve lutar para conquistar esta "racionalidade". Todavia, Gramsci nós lembra que apenas a vitória permanente (a na qual já pensava Lênin quando começa frisar a necessidade de uma revolução cultural que acompanhe e continue a política) pode quebrar a situação de subordinação - pois os subalternos sempre sofrem a iniciativa dos dominantes, até quando se rebelam. De toda maneira, o racional ou o irracional e sua definição remetem a algo "processual", que depende do seu "devir" histórico (entendido como resultado incessante de uma luta política, cultural e social), da posição hegemônica que conquista e mantém dentro de determinadas relações de força.

Desta forma, por um lado se entende melhor que, nos Cadernos, "irracional" não é interpretado como absolutamente irracional, mas como o lado que não consegue vencer na luta - social, cultural e política - deixando (não sem lutar e tentar se "impor") que o lado oposto se afirme como o "racional", ou seja, como universal generalizado socialmente (que é a única forma de universal verdadeiramente real e concreta) ou, ainda, como "história" ou práxis. Por outro lado, segundo Gramsci, esse lado irracional é, ao mesmo tempo, racional, pois é um "momento" necessário e imprescindível dele. De fato, para ele, o irracional não é absolutamente irracional, pois determina como o lado racional vai se desenvolver, isto é, um determinado desenvolvimento dele e não outro. Mas só depois do "fim" da luta, isto é, quando emerge o vencedor "permanente", se pode estabelecer o que é racional ou irracional - o que não pode ser feito, de modo nenhum, a priori. Por isso podemos falar que, de acordo com Gramsci, "racional" e "irracional" (ou "arbitrário") são conceitos "relativos", mas no sentido de dialeticamente relativos, pois essa relatividade é sempre o resultado de uma determinada dialética que acontece no (e coincide com o) processo histórico - sempre na medida em que e quando ela acontece.

Se quisermos trazer outro exemplo, para tentar esclarecer ainda melhor estes conceitos, podemos considerar o caso de um filósofo individual, cujo pensamento se torna "racional" ao ser aceito por uma comunidade de seres humanos. Aristóteles, e depois Ptolomeu, falavam que era a Terra que está no centro do universo, enquanto, ao contrário, para Aristarco era o Sol que ocupa aquela posição. A teoria de Aristarco não foi aceita. Para Gramsci, embora verdadeira, essa teoria fica "arbitrária"; ou seja, ela é sim uma verdade, mas, na sua fase inicial, ela falta da expansividade e eficácia necessária, que é o lado "racional" (que ganhará 
só muito depois). Para os seus contemporâneos e ainda depois, durante dum longo tempo, a teoria de Aristarco não faz sentido, contradiz a percepção e o senso comum. Por quanto paradoxal possa parecer, por si mesma ela não fica capaz de entregar para todos a certeza da realidade sobre a qual teoriza "cientificamente", e por isso não consegue se colocar como verdade, no sentido forte deste termo (compartilhada e reconhecida coletivamente). Como se sabe, séculos depois, a situação se inverterá. A teoria de Aristarco será demonstrada a racional.

Compreendemos assim ulteriormente que, nos Cadernos, o termo "arbitrário" ou "irracional" não é sinônimo de falso, mas tem a ver com algo que não consegue se tornar socialmente e historicamente eficaz (e, com efeito, vice-versa, ao limite, o próprio "falso" pode conseguir uma eficácia e se tornar "racional"); nem racional é sinônimo de verdadeiro. Esses termos ("racional", "irracional" e "arbitrário") tem a ver com o alcance, quantitativamente e qualitativamente, "político", hegemônico, ou seja, com a eficácia concreta (ou menos) duma verdade (ou falsidade) e, mais em geral, da atividade humana histórica. E só a que se torna racional, que chega a ser historicamente permanente, é a que pode ser plenamente considerada práxis (lembramos, em propósito, como Gramsci fale que para compreender a filosofia da práxis é preciso compreender a relação entre real e racional; então, se quisermos entender melhor essa filosofia, devemos também tentar entender o que significam os termos "real", "racional", etc., e a relação entre prática e teoria).

Aliás, a verdade de Aristarco se tornou racional não por causa de uma força intrínseca à linguagem dele, mas porque a nova verdade foi suportada por meio de lutas amarguíssimas e acirradissimas - nas quais, entre os que a suportavam, alguns acabaram até queimados vivos, como no caso de Giordano Bruno, em 1600. Os casos paradigmáticos, como este último, são a matriz de todos os outros - pois, para se afirmar como racional, qualquer ideia-atividade deve passar por uma luta, grande ou pequena, ou a pressupõe. Isso, para Gramsci significa que o que numa época se encontra de ("relativamente") arbitrário - mas que sempre possui, ao mesmo tempo, um núcleo "racional" - se torna ou pode se tornar "verdade" e "objetividade" na medida em que os grupos de seres humanos que acreditam nesse núcleo, lutam (culturalmente, politicamente e até militarmente) para afirmá-lo.

Em outras palavras, a verdade "científica" e "objetiva" - a da ciência natural, assim como, mais em geral, a da filosofia e de todas as linguagens teóricas que constituem o "saber" - não é eficaz por si mesma. Para não ficar "arbitrária", ela sempre deve conquistar uma "racionalidade". Gramsci repete que a clareza de uma ideia e verdade (individual ou de um 
grupo restrito) não é suficiente para sua difusão - isso constitui uma ilusão iluminista. Pois, o “dado" objetivo e verdadeiro inicial não tem autodifusividade nenhuma, mas se constitui como verdade e objetividade (reconhecida coletivamente) apenas num processo mais vasto $e$ articulado - que é sempre educativo-formador, ou pedagógico, ao implicar necessariamente uma obra de divulgação e crítica que nunca deixe de ser, ao mesmo tempo, uma grandiosa dialética coletiva, através da qual uma dada verdade, ainda patrimônio de um ou poucos, é conscientemente reconhecida por todos os membros de uma comunidade humana como tal, e na qual o "momento linguístico-cultural” atua um papel indispensável.

Por isso, para Gramsci, só ao se tornar (ao ser traduzida em) política, hegemonia no sentido amplo e, por isso, história (elemento "racional"), uma verdade se pode plenamente afirmar como "verdade objetiva" ou "científica". Só assim pode ela se unificar com a vida: ao reagir "pedagogicamente" sobre a realidade social e natural. Para que isto aconteça é necessário passar pela fase da assunção "subjetiva" (individual e coletiva) do dado "objetivo" inicial (que nunca é puramente e absolutamente objetivo). È muito importante destacar este ponto: que para Gramsci a cientificidade e objetividade de uma verdade são o resultado de um processo complexo. Neste último, uma verdade para ser plenamente tal, deve-se tornar verdade socialmente reconhecida e atuada. E um elemento se pode tornar tal só na medida em que seja também desenvolvida a consciência (coletiva e não apenas individual; "política" e não só teórica) de que ele é efetivamente uma verdade e na medida em que se trabalhe para torná-la real e concretamente eficaz. Por isso, dialeticamente, Gramsci, nos Cadernos, desenvolvendo uma ideia marxiana que se encontra nas Teses sobre Feuerbach, fala que, de fato, a verdade ou objetividade é sempre uma verdade ou objetividade "humanamente objetiva". Por ser considerada como algo que sempre se deve tornar "racional", ela não pode ser a verdade puramente objetiva do positivismo e determinismo; mas nem a verdade e objetividade do Idealismo e Espiritualismo. Contudo, isso não significa que Gramsci se entregue ao relativismo e ceticismo. A força e o poder da verdade - assim como, o seu limite - consistem no fato que é histórica. Mas a sua força e realidade se (de)mostram já "imediatamente", na luta hegemônica, enquanto ela se torne verdadeira ideologia capaz de mudar a ordem preexistente de determinadas forças sociais - que é o que aconteceu com a linguagem ideologia dos jacobinos (à qual já acenamos acima), a qual atraiu os camponeses na esfera de influência hegemônica da burguesia francesa, tirando-os da hegemonia da nobreza. Portanto, neste sentido a verdade é relativa, mas não no sentido do relativismo, e sim enquanto é um elemento que se torna "racional" - com uma durada e permanência relativa (onde relativa 
significa histórica). Desta forma, ao pensar a verdade como elemento racional, como política, Gramsci se furta também das acusações de ser um cético.

Nos Cadernos, tem também sentidos mais particulares da palavra "arbitrário" e "racional", como o artista que quer, a todo custo, inventar uma nova linguagem artística e não é entendido por ninguém. Gramsci o chama de "neolálico". Ele fica fazendo uma obra arbitrária, para ele. Mas toda obra de arte que é aceita por uma comunidade é racional. Ela é racional e aí consiste também o valor "político" da obra de arte, enquanto obra de arte. Nós entendemos que, em Gramsci, tem uma teoria estética a qual se baseia sempre sobre a capacidade de uma obra de um indivíduo a se difundir, se traduzir, ser compreendida por uma comunidade, apesar da vontade singular artista. Para ele, a arte, enquanto arte, contribui com a sua ação a formar e a transformar as pessoas que vivem numa comunidade e os seus modos de sentir: eis, muito em breve, os efeitos "políticos" da arte. Contudo, nós sabemos que tem autores como Benedetto Croce, grande filósofo italiano, idealista, que Gramsci critica a fundo naquele "Anti-Croce" que são os Cadernos, o qual afirmava que a arte não tem nada a ver com a política. Ao contrário, para Gramsci, a arte enquanto arte é "política" (no sentido mais amplo desta palavra, como dissemos antes) e é aqui que se pode medir uns dos pontos de distância máxima entre o filósofo da práxis e o idealista.

Não sei se agora está bastante clara a diferença entre racional e irracional. Eu poderia continuar...

\section{Revista Labor: Tranquilo. Bom, que outros autores do marxismo - o ponto 5 - fazem parte de sua estante pessoal, da sua formação, dos seus interesses?}

Rocco Lacorte - Eu sou leitor de Antonio Labriola, que é um marxista italiano, que é fonte dos cadernos do Gramsci. É um autor muito importante. Muito. Em Labriola, já encontramos essa questão da unidade do trabalho intelectual e manual. E Gramsci a retoma. Eu também estudei: muito Lênin, porque é uma fonte fundamental de Gramsci; e Engels, especialmente aquela carta para Joseph Bloch, de 1890, na qual começou todo o debate da relação entre estrutura e superestruturas, na Rússia da época entorno da revolução e na Itália. Todo esse debate coloca os pontos que, segundo meu ponto de vista, Gramsci encaminha à resolução através da elaboração da teoria da tradutibilidade, isto é, da possibilidade de traduzir entre teoria e prática, filosofia e política, estrutura e superestrutura, etc... Depois podemos falar das consequências do conceito que Gramsci elabora e das implicações a essa relação. 
Autores que também eu li foram Karl Korsch, que é um grande intérprete de Marx e Lukács; mas há outro autor marxista, um pouco menos conhecido, mas muito importante, que se chama James, C. R. L. James, que escreve algo muito importante sobre a função política da literatura na norte-américa - nos anos 1940, me parece. Escreve também um comentário à lógica de Hegel, do ponto de vista marxista. Um autor muito agudo. Sempre aconselho de lêlo - embora as considerações sobre a literatura sejam mais atuais das sobre Hegel. Então, as minhas leituras são, fundamentalmente, as dos clássicos: Marx, Engels, Lênin, Gramsci, entre outros. Para mim, dentro da vastíssima literatura marxista, ficam ainda os melhores para ler. Mas há também toda uma série de autores, como Korsch, Lukács, Benjamin e outros que eu li. Só que eu foco, ante de mais nada, sobre os clássicos, porque eu sou, digamos assim, um paleo-marxista. Não gosto muito de estruturalismo, pós-estruturalismo; li Althusser, esses autores, mas isso nunca me convenceu. Além da agudez, do Althusser ser muito agudo, por exemplo, por ajudar a entender o papel das superestruturas, acho que, a um certo ponto, ele desvia. Sobretudo quando tenta interpretar Gramsci, ele pega uns pontos fundamentais e faz reflexões fundamentais sobre Gramsci; mas não sei por que, a um certo ponto, ele desvia totalmente do sentido que Gramsci entregava àqueles pontos. Se quiser falar disso seria muito longo. Mas é isso, mais ou menos.

\section{Revista Labor: De todos esses autores, dos quais você acha que seria importante ter traduções para o português no Brasil que falta para o português, que ainda não são exploradas?}

Rocco Lacorte - Eu, na verdade, não conheço muito a literatura de traduções, exceto Gramsci, que falta ainda traduzi-lo a tudo. Sobre isso, tem todo um debate, no Brasil e entre estudiosos Brasileiros e italiános. Para mim, é necessário traduzir todo Gramsci, para entender como ele desenvolveu cada conceito; como, no seu pensamento, um conceito formulado em 1930, em 1932, você o encontra, às vezes, totalmente mudado. Você não pode perceber essa questão se não ler todos os textos de Gramsci. Se ficar só com antologias, você não pode perceber que Gramsci é um pensador que desenvolve, de forma crítica, o seu pensamento e como o desenvolve. A palavra "crítica" é fundamental para entender Gramsci. Há por exemplo, um parágrafo, o parágrafo 1 do caderno 7, no qual Gramsci fala o que Marx queria falar nas teses sobre Feuerbach, falando que a superestrutura, que a estrutura muda... Não me lembro agora com precisão, com exatidão. Mas Gramsci formula a interpretação sobre essa 
frase de Marx nas teses, falando que as superestruturas reagem sobre a estrutura. Depois, reelaborando o mesmo texto, a mesma linha, no caderno 10, um ano e meio depois, mais ou menos, ele substitui a palavra "superestrutura" pela palavra "homens" e fala: "são os homens que reagem sobre a estrutura”. O que está tentando fazer Gramsci? Gramsci quer dizer que não existem superestruturas que caminham sozinhas, na rua. São os homens que criam as superestruturas e são os homens que possibilitam essa reação, essa mudança das estruturas. Ele está concretizando o seu pensamento. Está tentando formular melhor uma ideia que teve um, dois anos antes e para esse fim está construindo uma nova linguagem, a qual seja mais adequada para expressar a originalidade das novas ideias marxistas. Nós vemos que, para Gramsci, é fundamental tentar formular os conceitos da forma mais exata possível, mais adequada e atualizada para explicar a realidade. Só se nós lermos todos os textos, nós conseguimos entender a operação que Gramsci está fazendo. Por isso estou convencido da necessidade de traduzi-lo tudo. Não é uma coisa de nenhuma importância, porque você vê como Gramsci às vezes muda radicalmente o jeito de ver. Em 1930, ainda dá muita importância para a estrutura como algo que dá impulso a superestruturas (embora, por outro lado, no mesmo período, mostre a sua insatisfação com isso, mas sem saber ainda entregar a ela a formulação lógico-linguística “certa”). A partir do final de 1930 e, depois, em 1931 e 1932, Gramsci fala com cada vez mais intensidade e clareza que também as superestruturas têm efeitos reais sobre as estruturas. Então, também as superestruturas dão impulso para a mudança da estrutura. Em suma, a um certo ponto, embora não pare de refletir sobre isso, ele chega a equilibrar a dialética entre os dois "momentos", coisa que, no começo, nos apontamentos escritos antes daquela época, fica bastante ambígua para um leitor. Influenciado pelo debate que teve na Rússia a partir daquela carta de Engels para Joseph Bloch, na qual Engels fala que ele e Marx, quando foram interpretar os fatos históricos sempre deram também importância aos fatos superestruturais, também, como fatores de mudança, Gramsci tenta interpretar essa carta de um jeito original a respeito de todo o debate que nasceu na Rússia da época da Revolução. Entre os vários protagonistas dele, nós sabemos que o Plechanov dava uma grande importância ao fator estrutural; e seria interessante estudar como a concepção da tradutibilidade de Gramsci vai mudar a ideia que nós temos da relação entre superestrutura e estrutura. Gramsci até parece abandonar essa dupla, a um certo ponto, para passar a falar apenas de "movimento histórico": há um ser humano, que é um "devir" (no sentido no qual já falamos mais acima), e não existem, estruturas, por um lado, e 
superestruturas, por outro; na realidade, existe apenas um conjunto de atividades em movimento. Ele não só fala isso, mas explica por que. Isso é interessante.

\section{Revista Labor: As principais categorias que subsidiariam a práxis educativa, já algo mais aplicado, como uma práxis educativa crítica. A práxis já se entenderia crítica, ficou redundante, mas...}

Rocco Lacorte - Com efeito, é o mesmo conceito de práxis que nós encontramos nas Teses sobre Feuerbach de Marx, que eu acho a categoria mais importante. Mas o que eu quero trazer para o debate no Brasil seria esse conceito de tradutibilidade, que é o conceito através do qual nós podemos explicar melhor o que é práxis. Porque práxis não é prática (como algo que contradiz à teoria); práxis é, por um lado, a realização (tradução) de uma teoria, e, por outro, por isso, uma prática imbuída de teoria. Ao mesmo tempo, dialeticamente, práxis é também um momento no qual nós potencializamos a prática através da sua elaboração teórica: a elaboração da teoria corresponde ao momento no qual a própria "prática" está se elaborando e fortalecendo, ou desenvolvendo. Aí, práxis, é entendida por Gramsci como tradução entre prática e teoria. Disso derivam uma série de implicações, que não podemos enfrentar aqui. Mas podemos intuir que o novo critério nós permite entender que se a prática é a realização crítica da teoria ela é, ao mesmo tempo, teoria e prática, só que é o momento da realização da teoria, e é teoria de uma forma e a um nível diferente do propriamente teórico. Por outro lado, podemos derivar que a própria teoria é, ao mesmo tempo, uma forma de prática, seja porque é a mesma prática que está se elaborando, que está se potencializando, seja por causa dos seus efeitos reais (que é algo sobre o qual já falamos acima). Então, para ele, práxis é um processo contínuo (quando e enquanto seja continuo), dialético, entre esses dois elementos que, então, não são propriamente dois, porque, depois de demonstrar de ser traduzíveis, nós vemos que não remetem a duas substâncias absolutamente diferentes e contraditórias, embora sejam diferentes e, para Gramsci, opostos dum tipo particular, isto é, contrários. O problema é que, às vezes, esse movimento dialético para, por falta do elemento intelectual, que é capaz de potencializar uma determinada realidade ou prática, ou do "prático" ou político que sabe tornar real uma teoria, ou melhor filosofia e concepção de mundo.

Para os idealistas, as ideias são sempre reais (e racionais), estão sempre em desenvolvimento. Para Gramsci, as ideias não se dão fora desse movimento de tradução. Aliás, elas se tornam reais só quando se tornam tais, só quando e enquanto são traduzidas em (uma determinada) 
realidade - o que, por outro lado, implica necessariamente não ignorar as necessidades reais a ser traduzidas para a teoria e, por sua vez, a tradução da teoria para a ideologia, prática ou política. Lá é a diferença fundamental entre a filosofia da práxis de Gramsci e o idealismo, que pode ser entendida a fundo só a partir da tradutibilidade. E aqui é o princípio que nós permite entender que práxis não é nem uma atividade puramente espiritual ou pura, no sentido idealista, nem o fato puro dos positivistas.

Então, o conceito de práxis, eu o considero central, norteador para criar uma pedagogia alternativa. Na tradição de pensamento ocidental predominante não se consegue ir além da divisão entre teoria e prática, dirigentes e dirigidos, intelectuais e povo, etc... e, a cada vez que se tentou solucioná-la, se entrou numa infinita série de contradições. Dentro desse quadro tradicional há extremos como, por exemplo, a reforma escolástica de Giovanni Gentile, que voluntariamente visou dividir a sociedade, ao criar escolas de alto nível para quem teria que se tornar intelectual e dirigente e as técnicas para os trabalhadores manuais (os quais na maioria dos casos são já filhos de outros trabalhadores manuais e desta forma ficam destinados a viver miseramente como os paí). Por outro lado se chegou, ao máximo, a pensar a integração de campo teórico e prático através da elaboração do conceito de “interdisciplinaridade". Contudo, Gramsci vai além, atualizando e desenvolvendo uns conceitos dos fundadores da filosofia da práxis, pois elabora um principio alternativo mais poderoso, precisamente o da tradutibilidade, pelo qual as divisões e barreiras tradicionais colapsam definitivamente. Em breve, ele afirma que, por exemplo, à medida que são traduzíveis, a filosofia (que para a tradição mencionada acima é uma disciplina teórica por excelência) contem implícitas seja a política que a economia (que para a tradição atividades práticas por excelência) e, portanto, a filosofia é também política e economia; o mesmo vale para os outros elementos: a política contem implicitamente a filosofia e a economia; e a economia contem implicitamente a fillosofia e a política. Não há espaço aqui para ilustrar mais sobre isso, embora o critério gramsciano tenha consequências e implicações de enorme importância; mas se entende o que Gramsci estava fazendo, isto é, desenvolver as bases filosóficas do marxismo, como filosofia autônoma. A tradutibilidade é o cerne de uma filosofia nova, é um critério pedagógico no qual teoria e prática não estão separadas (como no caso das disciplinas burgueses...), mas numa relação dialética, sintetizada pelo conceito de práxis (trabalho), o qual reúne as "duas" num processo que se dá historicamente. E se dá historicamente porque se dá politicamente. Quer dizer, na medida em que nós somos capazes de converter as ideias em política e transformar o mundo, aí se dá o processo, se dá o 
movimento. Na medida em que nós não criamos um pessoal capaz de fazer isso, não criamos as condições objetivas e subjetivas, ao mesmo tempo, para que esse movimento possa se dar, aí a práxis (a transformação revolucionária da realidade) para. Mas práxis é um conceito central para nortear uma pedagogia de caráter marxista, ou seja, alternativa e que não separe o ser humano em duas figuras, a teórica e a manual, a intelectual e a manual. E práxis eu colocaria ao lado do conceito de tradutibilidade. Eu sei que pareço um louco, porque sou o único que fala com uma insistência quase exagerada desse conceito, mas, acho que repetindo e tentando convencer os outros que é um conceito central, nós vamos entender que uma nova pedagogia, marxista, pode e deve ser baseada, fundando-se sobre o conceito de tradução - o que nós utilizamos para entender mais profundamente o conceito de práxis. Então, práxis + tradução.

Uma vez que entendemos isso, eu colocaria como norteador também o conceito de hegemonia - conceito desenvolvido por Lênin precisamente com a questão de educar e elevar culturalmente as massas russas e para "superar", ou melhor, traduzir (para atualizar) o de “ditadura do proletariado" e continuar a fase política e econômica da revolução através da inauguração de uma fase que fosse também e acima de tudo cultural. Colocar no mundo ocidental a questão de Lênin equivalia a elaborar ainda mais o conceito de hegemonia, traduzindo-o para o próprio Ocidente, pois nele os elementos culturais - a organização material voltada à "guerra de posição", a defender e desenvolver a frente "teórica" e ideológica (hoje encarnada pela mídia e que Gramsci chamava de "estrutura ideológica") eram muitos mais desenvolvidos do que na Rússia. Gramsci entendeu bem que, para mudar radicalmente o mundo ocidental, era necessário fazer um enorme trabalho pedagógico para elevar a cultura das massas ocidentais, italianas em particular, no caso gramsciano. Aí, a hegemonia corresponde ao momento no qual a classe subalterna desenvolve a sua luta também sobre o nível cultural, mas consciente de que o nível cultural pode ter e tem efeitos políticos, que a cultura - até a entendida num sentido mais estrito - não são só livros, mas expressa um nível e uma forma de atividade política. Porque, como fala Gramsci, tudo é política. Mas só se entende isso se nós estudamos a tradutibilidade. Só se sabemos que as atividades teóricas podem se traduzir em política, em ideologia, em prática e vice-versa; só se sabemos isso, entendemos o valor que Gramsci entrega para o conceito de política e para o conceito de cultura como política — valor que já lhe entregava Lênin, embora não tivesse elaborado de forma teórica completa o conceito marxista de tradução. Compreendendo este lado de Gramsci, compreenderemos melhor o que o próprio Lênin tinha entendido. Lênin não 
queria, simplesmente, fundar escolas, ele queria elevar o nível cultural, que significa a capacidade crítica do povo russo; para que cada elemento do povo ser capaz de escolher, de interpretar e analisar a realidade criticamente e autonomamente.

Então, nós precisamos desses conceitos para desenvolver uma pedagogia que visa a criar indivíduos que tenham uma capacidade crítica de análise da realidade, que sejam capazes de ler e interpretar a realidade de acordo com um ponto de vista autônomo, porque só assim podemos colocar as bases para transformá-la.

Mas ainda antes de fazer isso, devemos criar as condições para que os seres humanos adquirem a capacidade de traduzir e formular criticamente (linguisticamente) os problemas e da forma mais exata, correta, coerente e homogênea possível em relação à percepção e ao sentimento de determinadas necessidades sociais, as quais ficariam precisamente sentimento e intuição e não se transformariam em algo comunicável e mais claro - isto é, elaborado da forma "racional-linguística" - e portanto se manteriam ao nível da inexpressão ou duma expressão e formulação mais ou menos incompreensível e obscura, inadequada e fragmentária. Só assim conseguiremos ativar as (mentes das) pessoas, para não deixá-las passivas.

E, aqui, chegamos ao conceito de revolução passiva, que é também um conceito que eu introduziria dentro dessa pedagogia, ou seja, a participação ativa, do ponto de vista pedagógico, corresponde, em Gramsci, ao conceito de revolução ativa. Temos que ativar as capacidades críticas, não apassivizar, que é o que fazem as classes dominantes: tentam sempre passivizar, des-ativar, apagar a capacidade de pensar criticamente das massas, para que elas não se autonomizem. Mas tem mais categorias importantes, só que temos um tempo limitado.

\section{Revista Labor: O 7, também, creio que já está comentado, tem essa questão do Brasil. Não sei se você se sente à vontade para colocar, a partir de sua visão, ou se acha que é mais interessante nós investirmos nessa questão das suas leituras e essa questão da ampliação cultural.}

Rocco Lacorte - A pergunta é muito simples. Ultimamente, eu tenho lido Lênin, o qual abordou essa questão da revolução cultural, essa questão da conscientização. Então, estava lendo Lênin e Gramsci com referência a essa questão da conscientização, da revolução cultural. Então, estava relendo os últimos escritos de Lênin, a partir de 1921 para chegar a 1924. Em conexão com isso, eu estava interessado em recuperar o debate na época de Platão, 
porque Gramsci traz esse conceito socrático da consciência, do se tornar autoconsciente e fala de consciência socrática - o próprio Gramsci fala isso. Aí eu estava voltando aos meus velhos estudos filosóficos e retomei um pouco o estudo sobre Sócrates e Platão, para ver a relação entre conscientização e consciência política, relação entre o cidadão e a cidade. Então, as minhas leituras foram, ultimamente, Platão. Pelo que se sabe, Sócrates não escreveu nada, então fiz minha reconstrução a partir dos escritos de Platão. E Gramsci e Lênin, ultimamente. Depois, lí um livro de Ivan Illich sobre educação (que é uma coletânea de alguns escritos dele sobre educação) e ensaios para me ajudar a entender melhor a atmosfera na qual vivia Platão. Fiz essas leituras, ultimamente. Porque, ultimamente, quero trabalhar, quero entender melhor o papel da cultura em Gramsci como algo que é, ao mesmo tempo, "política". Estou estudando essa questão. Essas foram as leituras.

A respeito do Brasil, não me sinto de falar muito, porque ainda sou mais europeu, conheço melhor o meu país do que o Brasil. Mas a impressão que tenho tido, observando e falando com várias pessoas, é que a respeito do passado, além de todos os problemas, o que "está na mesa" é o fim de um ciclo político do PT, a questão de muitos jovens não se engajarem muito na política porque estão desconfiados por causa, digamos assim, das reformas prometidas e não mantidas por muitos políticos brasileiros. E a respeito do passado, eu vejo que, também no Brasil como na Europa, tem algo diferente, porque vejo que, por um lado, tem jovens que não querem se engajar na política. Por outro lado, tem quase uma superprodução de subjetividades: parece que todo mundo queira ser sujeito político e ninguém consiga encontrar pontos comuns, isto é, poucos pontos fundamentais sobre os quais ir de acordo para construir um movimento grande, de amplo respiro - especialmente num momento em que a crise mundial está se espalhando e pegando também no Brasil - que se torne capaz de enfrentar os desafios dos próximos anos (e esse fenômeno não me parece que aconteça apenas no Brasil). Então, por um lado, o lado negativo dessa subjetividade é que pode levar à dificuldade na criação de um movimento mais amplo e "homogêneo". O lado positivo é que tem todas essas subjetividades, que é algo que, no passado, acontecia muito menos, o que significa que o processo de conscientização crítica (política e cultural), por uma razão ou outra, tem tido um incremento notável. Isso é positivo e, nisso, foi decisiva a contribuição dos marxistas. Agora, se tornará cada vez mais necessário trabalhar para que essa produção de subjetividade e crítica se direcione num sentido positivo, para encontrar ponto de acordo, e, pelo menos, começar colocar e debater esta questão. 
São só poucos pontos, porque a minha fala sobre a situação política do Brasil e sul-américa seria muito superficial, ainda. Então, não queria falar mais disso.

\section{Revista Labor: E como é que o senhor vê a inserção do pensamento gramsciano nas cidades brasileiras? Tem uma visão clara disso?}

Rocco Lacorte - Tenho uma visão clara pelas universidades que eu frequentei. Vejo que há muito interesse nesse autor. Como disse, falta uma tradução integral e isso um pouco compromete um entendimento mais profundo do pensador, mas eu acho que não podemos pretender que qualquer pessoa comece a estudar um autor conhecendo tudo logo. Então, é bom começar grau a grau. Na verdade, eu tenho uma visão muito positiva, porque, por exemplo, na Itália — só comparando o que acontece na Itália com o Brasil —, na Itália o interesse dos jovens para Gramsci começou, assim, de novo a partir de 10 anos, 15 anos atrás, mas nas universidades, infelizmente, não é um autor muito estudado. Então, esse autor é apresentado e divulgado mais pelas atividades de instituições ou associações que ficam fora da universidade. Nas universidades brasileiras a situação é melhor. Por isso eu tenho uma visão positiva. Pelo menos aqui o Gramsci está sendo muito estudado, especialmente a respeito da Itália - embora a Itália, agora, tem um processo no qual tem vários jovens envolvidos nos estudos de Gramsci, mas nada comparado ao Brasil. Eu diria que, para começar, estamos muito bem a situação. Claramente, do ponto de vista de um estudo mais aprofundado, temos muito trabalho para fazer, porque eu acho que precisamos traduzir todos os escritos, mas é o que eu falava antes. Além disso, nas universidades brasileiras tem uma osmose maior entre universidade e sociedade civil, por exemplo a respeito das próprias universidade públicas italianas, mas ainda mais das nos Estados Unidos, onde as universidades mais importantes e difundidas são instituições particulares, aí a questão é ainda mais fechada. Mas acho que teríamos que desfrutar essa comunicação da universidade com a sociedade brasileira fazendo cursos de extensão, promovendo atividades culturais nas quase se poderia difundir o pensamento de Gramsci e outros autores ligados. O ambiente ainda é favorável. Tanto que tem pessoas da oposição, da direita, que começam a falar contra Gramsci, porque percebem o "perigo" desse autor (para eles, obviamente). Então, mais ou menos... 
Revista Labor: Por fim, um comentário mais pessoal. Seus interesses culturais são amplos, incluindo música, literatura, dentre outras questões, e seu pensamento incorpora essa riqueza. Você pode falar um pouco sobre a necessidade dessa ampliação cultural?

Rocco Lacorte - Eu acho que, primeiro de tudo, a filosofia tem que ser entendida, como faz Gramsci, ou seja, não só a filosofia com o filósofo, mas tudo o que tenha uma atividade crítica com o ser humano. Então, qualquer atividade é, ao mesmo tempo, filosofia. Este é o primeiro ponto. O segundo ponto que eu queria fazer é que ter interesses amplos ajudaria a desenvolver aquele ser humano desinteressado, ou seja, que não seja sempre tão especializado apenas numa atividade, porque desenvolver uma pessoa que tenha uma ampla variedade de interesses ajuda a desenvolver o pensamento crítico através da comparação entre as várias atividades. Podemos fazer um exemplo muito simples: quando eu planejo uma casa, por exemplo, o que tenho na cabeça muitas vezes não corresponde ao que vai ser a realização daquela casa. Ao realizar o meu projeto, eu, por exemplo, descubro que as portas, assim como eram planejadas idealmente, não cabem na realidade. Aí tenho que mudar a forma das portas. Aí vou criticar, durante minha atividade prática, o que eu tinha desenvolvido teoricamente. Através de uma atividade diferente, neste caso de uma prática, a do pedreiro, eu consigo desenvolver criticamente a atividade teórica, a do arquiteto e vice-versa, pois uma reage sobre a outra dialeticamente. Então, quantas mais atividades nós aprendemos e fazemos, tanto melhor podemos nos formarmos como seres críticos, capazes de analisar a realidade autonomamente e de viver e enfrentar a realidade. Então, eu sempre fui a favor de começar desde meninos, a fazer quantas mais atividades possíveis, de caráter teórico e prático. Essa é a minha ideia, em extrema síntese.

Revista Labor: Muito interessante. Nós agradecemos.

Rocco Lacorte - Agradeço a vocês. 